\title{
Testosterone Excretion Rates in Normal Males and Males with an XYY Complement
}

\author{
B. T. RUDD, O. M. GALAL, and M. D. CASEY \\ From the Institute of Child Health, University of Birmingham; the Department of Genetics, University of Sheffield; \\ and the Centre for Human Genetics, Manchester Road, Sheffield
}

The incidence of males with an XYY chromosome complement in a maximum security hospital was found to be 3\% (Jacobs et al., 1965). These males were exceptionally tall, and it was found that 1 in 3 of the men of over $6 \mathrm{ft}$. $(183 \mathrm{~cm}$.) in this hospital had an XYY chromosome constitution. This very high incidence in an over- $6 \mathrm{ft}$. group was confirmed in a special hospital for the subnormal (Casey et al., 1966). Apart from their tall stature no other abnormality has been detected in these XYY males.

The behavioural disorders and pattern of the crime among these XYY males has been extensively investigated (Price and Whatmore 1967a, b). From these studies it was suggested that the extra ' $Y$ ' chromosome was a factor contributing to their disorder of personality and their early conflict with the law.

It was thought of some interest to know if the presence of an additional ' $Y$ ' chromosome had any influence on the secretion of the male sex hormone, testosterone. In the present study, urinary testosterone excretion rates have been measured in two groups of males with an XY constitution and a third group of males with an XYY constitution.

\section{Materials and Methods}

Fifteen males who were detained at the special hospital, Rampton, have been studied. Of these 15,9 were shown to be XYY constituted (Group 1) (Casey et al., 1966). The remaining 6 subjects had a normal XY complement (Group 2).

In addition, urinary testosterone excretion rates were measured in 6 normal males (Group 3) (members of staff), the results of which have been used as a reference point for the interpretation of the testosterone excretion rates obtained from the 15 male in-patients.

Collections of 24-hour urine specimens were obtained from all the subjects, and aliquots stored at $4^{\circ} \mathrm{C}$. until

Received December 14, 1967. analysed. The testosterone excreted as the glucuronideo was hydrolysed with betaglucuronidase enzyme. Pre-ir liminary fractionation of the liberated testosterone was accomplished by a modification of the procedure of Ibayashi et al. (1964). An additional paper chromatographic step was employed using the light petroleum:을 dekalin:methanol system of Bush (1961) to ensure the separation of testosterone from epitestosterone.

The testosterone fraction obtained from the paper chromatographic step was acetylated and rerun on a thin- $\frac{}{3}$ layer chromatoplate in the system ethyl acetate:benzene $(1: 3)$. The testosterone acetate fraction was subse- quently.quantitated by a fluorimetric procedure (Koren- $\vec{\bullet}$ man, Wilson, and Lipsett, 1963), using testosterome acetate for the standard curve. The results reporte here are expressed in terms of testosterone acetate.

\section{Results}

Table I documents the physical parameters and the testosterone excretion rates in the 15 men de- $\overline{0}$ tained at Rampton (Groups 1 and 2). Table II 3 shows the same parameters obtained from normal men (Group 3).

The mean height was identical in Groups 1 and 2 $(184 \mathrm{~cm}$.$) and slightly less in Group 3(176 \mathrm{~cm}$.). The mean age for the XYY males (Group 1) was 29.1 years, for the XY males 25.6 years (Group 2), and for the normal group 31.6 years (Group 3). The means for the body parameters of weight and surface area were similar in all 3 groups.

We were unable to demonstrate a clear correla- $\frac{D}{O}$ tion between either weight or surface area and the testosterone excretion rate. The Fig. illustrates $\widetilde{\sigma}$ distribution of testosterone excretion rate in the $3 \mathrm{~N}$ groups of subjects. The mean excretion rate for N Groups 1 and 2 was higher than Group 3, irrespective of the way the data were expressed. In particular, 7 out of $9(77 \%)$ of the men with an $\frac{0}{\Phi}$ XYY complement had excretion rates that were $\stackrel{\oplus}{\rightarrow}$ outside +2 SD from the mean testosterone excre286 
TABLE I

GROUPS 1 AND 2: RAMPTON DETAINEES

\begin{tabular}{|c|c|c|c|c|c|c|c|}
\hline Subject No. & $\begin{array}{l}\text { Age } \\
(\mathrm{yr} .)\end{array}$ & Weight (kg.) & $\begin{array}{c}\text { Height } \\
\text { (cm.) }\end{array}$ & $\begin{array}{l}\text { Body Surface } \\
\text { Area }\left(\mathrm{m} .{ }^{2}\right)\end{array}$ & $\begin{array}{l}\text { Testosterone } \\
(\mu \mathrm{g} . / 24 \mathrm{hr} .)\end{array}$ & $\begin{array}{l}\text { Testosterone } \\
(\mu \mathrm{g} . / \mathrm{kg} . \mathrm{b} . \mathrm{wt} .)\end{array}$ & $\begin{array}{c}\text { Testosterone } \\
\left(\mu \mathrm{g} . / \mathrm{m} .^{2}\right. \\
\text { Body Surface } \\
\text { Area) }\end{array}$ \\
\hline $\begin{array}{l}1 \\
2 \\
3 \\
4 \\
5 \\
6 \\
7 \\
8 \\
9\end{array}$ & $\begin{array}{l}59 \\
19 \\
59 \\
23 \\
22 \\
19 \\
23 \\
38 \\
22\end{array}$ & $\begin{array}{l}\text { Group } \\
87 \cdot 7 \\
78 \cdot 6 \\
79 \cdot 5 \\
64 \cdot 5 \\
78 \cdot 2 \\
70 \cdot 9 \\
79 \cdot 5 \\
72 \cdot 7 \\
59 \cdot 1\end{array}$ & \begin{tabular}{|c|}
1 Male Patier \\
184 \\
181 \\
190 \\
180 \\
189 \\
181 \\
192 \\
181 \\
180
\end{tabular} & \begin{tabular}{|c|} 
ts with XYY Ch \\
2.12 \\
2.00 \\
2.08 \\
1.84 \\
2.07 \\
1.92 \\
2.11 \\
1.95 \\
1.77
\end{tabular} & \begin{tabular}{|c|} 
romosomes \\
113 \\
87 \\
150 \\
132 \\
295 \\
255 \\
216 \\
174 \\
121
\end{tabular} & $\begin{array}{l}1 \cdot 3 \\
1 \cdot 1 \\
1 \cdot 9 \\
2 \cdot 0 \\
3 \cdot 8 \\
3 \cdot 6 \\
2 \cdot 7 \\
2 \cdot 4 \\
2 \cdot 0\end{array}$ & $\begin{array}{r}53 \cdot 3 \\
43 \cdot 5 \\
72 \cdot 1 \\
71 \cdot 7 \\
142 \cdot 5 \\
132 \cdot 8 \\
102 \cdot 4 \\
89 \cdot 2 \\
68 \cdot 4\end{array}$ \\
\hline $\begin{array}{l}\text { Mean } \\
\text { Range }\end{array}$ & $\begin{array}{c}29 \cdot 1 \\
(19-59)\end{array}$ & $\begin{array}{c}74 \cdot 5 \\
(59 \cdot 1-87 \cdot 7)\end{array}$ & $\begin{array}{c}184 \\
(1 \cdot 80-1.92)\end{array}$ & $\begin{array}{c}1 \cdot 98 \\
(1 \cdot 77-2 \cdot 12)\end{array}$ & $\begin{array}{c}171 \\
(87-295)\end{array}$ & $\begin{array}{c}2 \cdot 3 \\
(1 \cdot 1-3 \cdot 8)\end{array}$ & $\begin{array}{c}86 \cdot 2 \\
(43 \cdot 5-142 \cdot 5)\end{array}$ \\
\hline $\begin{array}{l}1 \\
2 \\
3 \\
4 \\
5 \\
6\end{array}$ & $\begin{array}{l}27 \frac{1}{2} \\
25 \\
23 \\
21 \frac{1}{2} \\
33 \\
21 \frac{1}{2}\end{array}$ & $\begin{array}{l}74 \cdot 1 \\
72 \cdot 7 \\
66 \cdot 4 \\
72 \cdot 3 \\
78 \cdot 9 \\
66 \cdot 8\end{array}$ & \begin{tabular}{|c|} 
Group 2 Male \\
181 \\
183 \\
182 \\
185 \\
192 \\
180
\end{tabular} & \begin{tabular}{|c|} 
Patients-Norm \\
1.96 \\
1.96 \\
1.88 \\
1.97 \\
2.10 \\
1.86
\end{tabular} & \begin{tabular}{|c|} 
al (XY) Chrom \\
117 \\
204 \\
115 \\
95 \\
127 \\
101
\end{tabular} & \begin{tabular}{r|} 
nosomes \\
1.6 \\
2.8 \\
1.7 \\
1.3 \\
1.6 \\
1.5
\end{tabular} & $\begin{array}{r}59 \cdot 7 \\
104 \cdot 1 \\
61 \cdot 2 \\
48 \cdot 2 \\
60 \cdot 5 \\
54 \cdot 3\end{array}$ \\
\hline $\begin{array}{l}\text { Mean } \\
\text { Range }\end{array}$ & $\begin{array}{c}25 \cdot 3 \\
21 \cdot 5-27 \cdot 5\end{array}$ & $\begin{array}{c}71 \cdot 7 \\
(66 \cdot 4-74 \cdot 1)\end{array}$ & $\begin{array}{c}184 \\
(181-192)\end{array}$ & $\begin{array}{c}1.95 \\
(1 \cdot 86-2 \cdot 10)\end{array}$ & $\begin{array}{c}126 \\
(95-204)\end{array}$ & $\begin{array}{c}1 \cdot 7 \\
(1 \cdot 3-2 \cdot 8)\end{array}$ & $\begin{array}{c}64 \cdot 7 \\
(48 \cdot 2-104 \cdot 1)\end{array}$ \\
\hline
\end{tabular}

TABLE II

GROUP 3: NORMAL MALES (CLINICAL AND LABORATORY STAFF)

\begin{tabular}{|c|c|c|c|c|c|c|c|}
\hline Subject No. & $\begin{array}{l}\text { Age } \\
\text { (yr.) }\end{array}$ & Weight (kg.) & Height (cm.) & $\begin{array}{c}\text { Body Surface } \\
\left.\text { Area (m. }{ }^{2}\right)\end{array}$ & $\begin{array}{l}\text { Testosterone } \\
(\mu \mathrm{g} . / 24 \mathrm{hr} .)\end{array}$ & $\begin{array}{c}\text { Testosterone } \\
(\mu \mathrm{g} . / \mathrm{kg} . \mathrm{b} . \mathrm{wt} .)\end{array}$ & $\begin{array}{l}\text { Testosterone } \\
\text { ( } \mu \mathrm{g} . / \mathrm{m}^{2} \text { Body } \\
\text { Surface Area) }\end{array}$ \\
\hline $\begin{array}{l}1 \\
2 \\
3 \\
4 \\
5 \\
6\end{array}$ & $\begin{array}{l}32 \\
31 \frac{3}{4} \\
25 \\
35 \\
32 \\
34\end{array}$ & $\begin{array}{l}72 \cdot 7 \\
74.5 \\
56 \cdot 8 \\
80.7 \\
82.6 \\
82.7\end{array}$ & $\begin{array}{l}179 \\
171 \\
167 \\
172 \\
185 \\
184\end{array}$ & $\begin{array}{l}1.91 \\
1.84 \\
1.65 \\
1.96 \\
2.08 \\
2.06\end{array}$ & $\begin{array}{l}98 \\
54 \\
94 \\
94 \\
76 \\
63\end{array}$ & $\begin{array}{l}1.3 \\
0.7 \\
1.6 \\
1.2 \\
0.9 \\
0.8\end{array}$ & $\begin{array}{l}51.3 \\
29.3 \\
57.0 \\
48.0 \\
36.5 \\
30.6\end{array}$ \\
\hline $\begin{array}{l}\text { Mean } \pm 2 S D \\
\text { Range }\end{array}$ & $\begin{array}{c}31 \cdot 6 \\
(25-35)\end{array}$ & $\begin{array}{c}75 \cdot 0 \\
(72 \cdot 7-82 \cdot 7)\end{array}$ & $\begin{array}{c}176 \\
(167-185)\end{array}$ & $\begin{array}{c}1.92 \\
(1.84-2.08)\end{array}$ & $\begin{array}{c}80 \cdot 0 \pm 37 \cdot 0 \\
(54-98)\end{array}$ & $\begin{array}{l}1 \cdot 1 \pm 0 \cdot 7 \\
(0 \cdot 7-1 \cdot 6)\end{array}$ & $\begin{array}{l}42 \cdot 1 \pm 22 \cdot 7 \\
(29 \cdot 3-57 \cdot 0)\end{array}$ \\
\hline
\end{tabular}

A statistical evaluation of the data using the Student ' $t$ ' test (Brownlee, 1960) revealed that the values for the testosterone excretion rates were significantly higher for Group 1 as compared with Group $3(\mathrm{p}<0.01)$. Furthermore, the values for Group 2 were also significantly higher than the values in Group $3(p<0.05)$. In addition, those patients with an XYY complement (Group 1) had excretion rates that were not significantly different from those patients with a normal XY complement (Group 2).

\section{Discussion}

A physiological role for testosterone is well established for the male from the foetal stage of development (Goldman, Yakovac, and Bongiovanni, 1966) and again when puberty intervenes.

Sex reorientation to the female type has been most elegantly demonstrated in the rat when an anti-androgenic agent is administered at the early stages of male foetal development (Neumann and Elger, 1965).

A role for testosterone that influences behavioural patterns not associated with the sexual drive of males is less evident. The present investigation has not elucidated whether or not a clear relation exists between antisocial behaviour and increased testosterone excretion. There is evidence, however, from this study, that patients with an XYY complement and patients with normal sex chromosomes can produce more testosterone than normal men who are not under detention.

It has been demonstrated that the levels of plasma testosterone in normal males show a diurnal variation (Resko and Eik-Nes, 1966). The increased excretion of testosterone found in the patients with $\mathrm{XY}$ and XYY chromosomes might be attributable to a loss of the normal diurnal variation. It could be postulated that the enforced detention is a sufficient factor contributing to a loss of diurnal rhythm. 

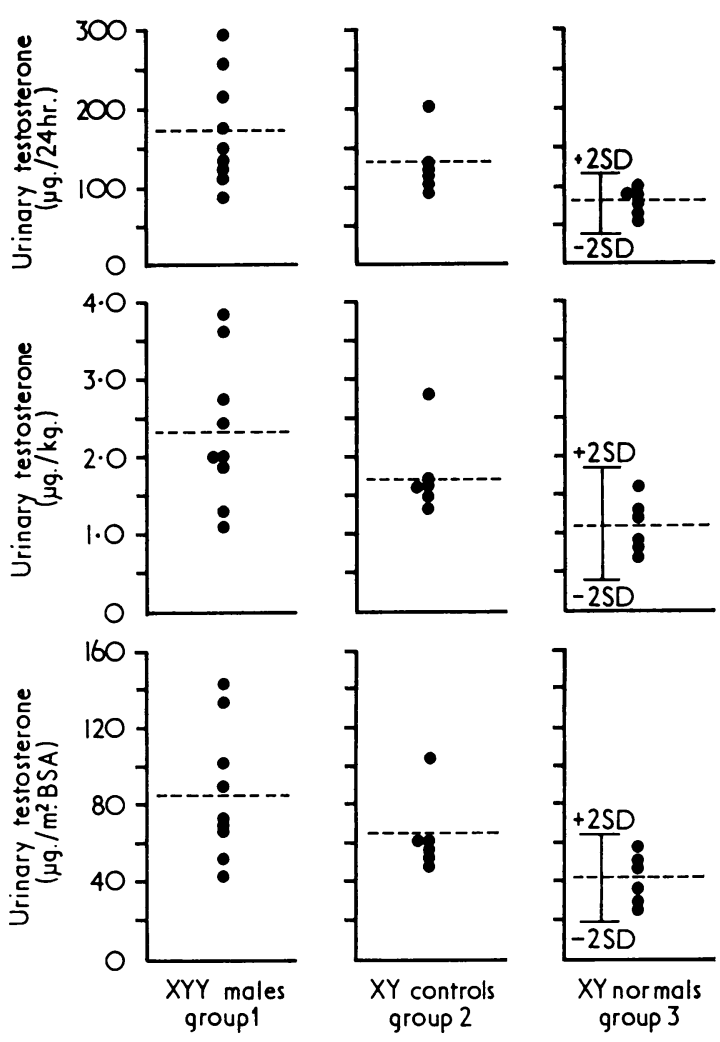

FIG. Testosterone excretion rates.

Such a loss of normal rhythm may result in an increased and variable excretion of testosterone in the urine of these patients.

The proportion of the excreted testosterone which was biologically active also remains unknown. The measurement of the non-conjugated fraction circulating in plasma under conditions of adrenal suppression using analogues of cortisol might be revealing, as has been shown in other studies of androgen excess (Vermeulen, 1965).

\section{Summary}

Urinary testosterone excretion rates have been measured in 15 patients detained at the special hospital, Rampton. Of these patients, 9 had an $\frac{2}{\infty}$ XYY chromosomal complement and the remaining 6 ه had a normal male sex chromosome pattern. Almost $\stackrel{\mathbb{D}}{\overparen{D}}$ all these patients had higher excretion rates of $\stackrel{\oplus}{+}$ testosterone when compared to normal healthy $\overrightarrow{\vec{F}}$ men. It has been postulated that patients under detention have increased testosterone excretion rates due to changes in the mechanisms controlling the diurnal rhythm of testosterone. The results do not suggest that an additional ' $Y$ ' chromosome has an influence on the excretion of the male sex on hormone.

We are particularly indebted to Dr. D. R. K. Street, $\vec{\omega}$ the Medical Superintendent, and the nursing staff of the Special Hospital at Rampton, for their close co-operation throughout these studies. Our grateful thanks are due ir to Professor D. V. Hubble for the facilities to pursue this $A$ work and to Dr. J. H. Edwards for his constructive is criticism.

\section{REFERENCES}

Brownlee, K. A. (1960). In Industrial Experimentation, 4th ed. H.M.S.O., London.

Bush, I. E. (1961). In The Chromatography of Steroids, pp. 2 and 336-346. Pergamon Press, Oxford.

Casey, M. D., Blank, C. E., Street, D. R. K., Segall, L. J., McDougall, J. H., McGrath, P. J., and Skinner, J. L. (1966). YY chromosomes and antisocial behaviour. Lancet, 2, 859.

Goldman, A. S., Yakovac, W. C., and Bongiovanni, A. M. (1966§ Development of activity of $3 \beta$ hydroxysteroid dehydrogenase human fetal tissues and in two anencephalic newborns. $\mathcal{F}$. clim. Endocr., 26, 14.

Ibayashi, H., Nakamura, M., Murakawa, S., Uchikawa, T., Taniok T., and Nakao, K. (1964). The determination of urinary testosterone using thin layer chromatography and gas chromatography. Steroids (San Francisco), 3, 559.

Jacobs, P. A., Brunton, M., Melville, M., Brittain, R. P., and McClement, W. F. (1965). Aggressive behaviour mental subnormality and the XYY male. Nature (Lond.), 208, 1351.

Korenman, S. G., Wilson, H., and Lipsett, M. B. (1963). Testosterone production rates in normal adults. $\mathcal{f}$. clin. Invest., 42 , 1753.

Neumann, F., and Elger, W. (1965). Physiological and psychical intersexuality of male rats by early treatment with anti-androgenic agent. Acta endocr. (Khb.), Suppl. 100, 174.

Price, W. H., and Whatmore, P. B. (1967a). Behaviour disorders and pattern of crime among XYY males identified at a maximum security hospital. Brit. med. $\mathcal{F} ., 1,533$.

, and - (1967b). Criminal behaviour and the XYY male. Nature (Lond.), 213, 815.

Resko, J. A., and Eik-Nes, K. B. (1966). Diurnal testosterone levels in peripheral plasma of human male subjects. $\mathcal{F}$. clin. Endocr., 26, 573.

Vermeulen, A. (1965). In Androgens in Normal and Pathological Conditions. Proc. 2nd Symposium on Steroid Hormones, Ghent, Vol. 1, p. 71. Excerpta Medica Foundation, Amsterdam. 